\title{
The Effectiveness of Blended Learning in Increasing Prospective Physics Teacher Students' Learning Motivation and Problem- Solving Ability
}

\section{K. Suma ${ }^{1 *}$, I.N.P. Suwindra ${ }^{2}$, Rai Sujanem ${ }^{3}$}

1,2,3 Physics Education Department, Universitas Pendidikan Ganesha, Singaraja, Indonesia Email: ketut.suma@undiksha.ac.id, suwindra@undiksha.ac.id, raisujanem@undiksha.ac.id

\begin{abstract}
Advances in information technology have led to innovative learning methods that combine traditional and online learning, known as blended learning. This pre-experimental study aims to analyze the effectiveness of blended learning in increasing prospective physics teacher students' learning motivation and problem-solving ability. There were 14 students who participated in this study. They were involved in $70 \%$ of face-to-face learning and $30 \%$ in online learning. The data of learning motivation were collected by the questioner and the data of problem-solving ability were collected by test. The research hypotheses were tested by non-parametric statistics, namely the sign test. The results of the study indicate that the pre-test score mean of learning motivation was 67.21 (SD=5.45), which was in the medium level and the post-test score mean was 74.98 (SD=5.93), which was at a high level. The pre-test score means of problem-solving was 33. $43(S D=4.90)$ which was at a lowlevel and the post-test score mean was $63.54(S D=2.35)$, which was at a moderate level. The one side sign test shows the calculated $Z_{C}=3.43$, which was higher than standard $Z$ at a $5 \%$ significance level. The mean score of prospective physics teacher students' learning motivation and problemsolving ability between before and after learning was significantly different. From this finding can be concluded that blended learning effective in increasing prospective physics teacher students' learning motivation and problem-solving ability.
\end{abstract}

Keywords: Blended Learning, Learning Motivation, Problem-Solving Ability

\section{Introduction}

Mathematical Physics course is one of the compulsory subjects for physics majors and physics education in universities in Indonesia. In the physics education department at the Universitas Pendidikan Ganesha, mathematical physics courses are divided into two courses namely Mathematical Physics I offered in the odd semester and Mathematical Physics II offered in even semester. Mathematical physics courses aim to provide a mathematical foundation for advanced physics courses such as mechanics, electricity and magnetism, optical and wave physics, quantum physics, statistical physics, and solids state physics (Kurikulum Fisika KKNI 2016). This course also provides an introduction to mathematical methods for solving mathematical problems that appear in the above branches of physics.

In general, Mathematical Physics learning in universities is held face-to-face in class. Learners are present in class and all learning activities are carried out in class. The commonly used methods are lectures, discussions, and group work. All of these face-to-face activities require direct responses from class members. All learning transactions are planned, implemented, controlled, and evaluated by the instructor. Learners only follow the learning scenario developed by the teacher. The learning process takes place only in a tightly scheduled time and place. Students get fewer opportunities to plan, implement, and control their own learning. Given the limited learning time, the interaction between students and/or students is very limited. As a result, not all students have the opportunity to be optimally

\footnotetext{
${ }^{*}$ Corresponding author.

Received 24 November 2019; Accepted 1 August 2020; Available online 01 September 2020 (C) 2020 JPI. All Rights Reserved
} 
involved. Most students tend to be passive and only wait for the direction/guidance of the teacher. Starting from these weaknesses, there is a need for alternative methods that are more flexible, provide opportunities for students to manage and control their own learning, with learning at anytime, anywhere, and utilize a variety of media and learning resources. However, this alternative learning method still provides opportunities for direct interaction between students and/or students to foster social relations and provide direct guidance.

The development of educational technology today has improved the learning environment that provides a variety of tools that enable the fulfillment of the diverse needs of students. Sophisticated network systems have caused a revolution in education that enables the application of alternative learning methods "anytime and anywhere" for online learners around the world (Oh \& Lim, 2005). Through online learning, students can get a variety of educational content and build multi-way communication with other students and teachers. (Uğur et al., 2011). Students control their learning environment, learning speed, information, activities, and time management (Jung, 2001). Advances in web technology have encouraged educators to create teaching methods that appropriate to the learning styles and students' needs (Yeop et al., 2016). While online learning guarantees flexibility and the achievement of competencies that difficult to achieve in real classrooms, face-to-face interaction allows social interaction needed as a guide for students. Integrating the best aspects of e-learning and traditional learning accompanied by the application of the information technology system creates what is called Blended Learning.

Blended learning is a combination of face-to-face learning and online learning (Briggs, 2014; Dziuban et al., 2018; Graham, 2006; Stacey \& Gerbic, 2009; Volchenkova, 2016; Wong et al., 2014). The Australian National Training Authority as cited by (Shivam \& Singh, 2015) states "blended learning is a combination of traditional learning and a webbased approach". This model will become the main model in the future (Yen \& Lee, 2011) and allows the material, students, and teachers not in the same space (Williams, N.A. \& Christie, 2008).

With blended learning students still have the opportunity to have direct social interaction and get guidance from the teacher. Kaur, (2013) state "blended Learning is provided by the effective combination of different modes of delivery, models of teaching and styles of learning which are exercised in an interactively meaningful learning environment". Sophisticated network systems have caused a revolution in education that allows the application of alternative learning methods "anytime and anywhere" for online learners around the world (Oh \& Lim, 2005).

Studies show that blended learning is effective in various fields. (Wichadee, 2013) indicated that blended learning was effective to develop language skills. Student satisfaction from the four learning style groups differed significantly. In Biology teaching, Asquith, (2011) states that student scores who study with blended learning and face to face differ significantly. Yapici \& Akbayin, (2012) conclude Blended learning can significantly improve attitudes towards the internet and contribute more to students' learning outcomes in Biology than traditional learning. In mathematics learning, Lin et al., (2017) state that blended learning has a positive effect on learning outcomes and attitudes toward mathematics learning. Waynick, (2015) has investigated the effectiveness of blended learning in mathematics, of 12th-grade students. He found that blended learning more effective in increasing students' understanding than traditional learning. In pre-calculus algebra course Yushau, (2006) found that students show a positive attitude towards mathematics and computers.

Evidence of the effectiveness of blended learning as above is enough to be used as a reference to implementing blended learning methods in the mathematical physics course. Mathematical physics which focuses on mathematical concepts and their application in physics (Arslan \& Arslan, 2010) has a high-level complexity. Because of that, in learning students need guidance through direct interaction with instructors in face-to-face learning activities. On the other hand, natural phenomena formula in mathematical language in the form of simulations and/or animations available widely and freely on the internet. Various media and learning resources of mathematical physics easily accessed at anytime and 
anywhere via the internet. This means that mathematical physics can also be taught through blended learning methods to develop learning motivation and problem-solving abilities. Increased learning motivation is one indicator of the effectiveness of learning strategies. Meanwhile, problem-solving skills are the ultimate goal of mathematics physics courses.

Motivation to learn is a process that gives enthusiasm, direction, and persistence in behavior (Santrock, 2007). Motivated behavior is behavior that is full of energy, directed, and enduring. Oxford Dictionary, (2013) define motivation "as the desire or willingness to do something, the condition of being eager to act or work, the power or influence that causes someone to do something". Motivation consists of internal and external motivation. Intrinsic motivation is motivation to do something for the sake of something itself (own goals). Extrinsic motivation is motivation wherein doing something to get something else (a way to meet a goal), it is often influenced by external incentives such as rewards and punishment. Student motivation levels will be reflected in their involvement and contribution to the learning environment (Gopalan et al., 2017). Mazumder, (2014) states "to succeed in higher education, a learner must develop a higher level of motivation towards learning and develop proper strategies to meet their respective goals".

Problem-solving is one of the primary goals of physics courses (Shishigu et al., 2018). Toluk \& Olkun (Çaliskan et al., 2010) define "problem-solving as a cognitive process that requires memory and uses it to choose the right activities and work systematically". Problem-solving is the process to find the solution of problem. Polya quoted by (Cildir, 2019) state problem-solving consists of four-stage, namely: (1) understanding the problem, (2) state the solution plan, (3) execute the plan, and (4) evaluate the results. Heller et al., (1992) describes more detail the problem-solving in physics into five stages namely: (1) understanding problems, (2) the ability to describe problems into physical descriptions, (3) formulating physical phenomena into mathematical problems, (4) planning solutions, (5) executing solutions, and (6) testing the correctness of the solution. Problem-solving can include operating a mathematical system or operating system involving critical thinking skills. The problem of mathematical physics is a mathematical proposition about physical phenomena that must be solved. So, to solve mathematical physics problems in addition to understanding the problem-solving steps students must also understand the physical phenomena that are represented through mathematical language.

The aim of this study is to analyze the effectiveness of blended learning in increasing prospective physics teacher students learning motivation and problem-solving ability. The effectiveness of blended learning in this study is measured by the difference in students' learning motivation and problem-solving ability between before and after treatment. The questions of the study that will be answered are: (1) is there a difference in prospective physics teacher students' learning motivation between before and after blended learning? And (2) is there a difference in prospective physics teacher students' problem-solving ability between before and after blended learning?

\section{Method}

The one-group pre-test-post-test design was used to answer the research questions. There were 14 prospective physics teacher students participated in this study. They took the mathematical physics course in the third semester of the 2019 academic year. Blended learning was carried out with a portion of $70 \%$ face-to-face and $30 \%$ online with Google Classroom platform.

The data collected in this study were the prospective physics teacher students' learning motivation and problem-solving ability score. Both data were collected by the test technique. Learning motivation data were collected by the questionnaire that includes 5 dimensions, namely (1) self-efficacy, (2) active learning strategy, (3) learning values, (4) performance goals, (5) achievement goals, (6) learning stimulation environment. Each item of the questionnaire consists of 5 alternative answer choices, namely: strongly agree, agree, fairly agree, disagree, strongly disagree. Scores for each alternative answer choice are as follows: strongly agree $=5$; agree $=4$, fairly agree $=3$, disagree $=2$, and strongly disagree $=1$. The reliability of this questionnaire is $r=0.83$. The data of problems solving ability scores were 
collected by problem-solving ability test, which has a reliability index $r=0.80$. This test in the form of essays consisting of 5 items. The scoring for each item based on problem-solving aspects namely (1) problem visualization, (2) mathematical description, (3) plan of the solution, (4) executed the plan; and (5) check of the solution.

Data on prospective teacher students' learning motivation and problem-solving abilities were analyzed with non-parametric statistics and descriptive techniques. Descriptive analysis was performed to describe the mean score and standard deviation (SD). The level of the mean score qualification was determined by criteria as shown in Tabel 1.

Table 1. Mean Score Level Criteria

\begin{tabular}{cc}
\hline Interval mean score & Level of qualification \\
\hline $85-100$ & very high \\
$70-84$ & High \\
$55-69$ & Medium \\
$45-54$ & Low \\
$<45$ & very low \\
\hline
\end{tabular}

There are two null hypotheses tested in this study, namely: (1) there is no difference in the learning motivation of prospective physics teacher students between before and after blended learning, (2) there is no difference in the problem-solving of prospective physics teacher students between before and after blended learning. The research hypotheses were tested with non-parametric statistics, the sign test. The formula is

$$
Z=\frac{X-\mu}{\sigma}
$$
$(+)$ or $(-)=0.5$

Where, $\mu=n p$, with $n=$ number of samples, and $p=$ probability of obtaining the sign

$\mathrm{X}=$ number of positive signs minus 0.5

$$
\sigma=\sqrt{n p q}, \text { with } q=1-p=(0.5)
$$

Hypotesis testing was done at a significant level of $5 \%$. $H_{0}$ is rejected if $Z>Z_{\alpha}$ (Critical value).

\section{Results and Discussion}

Table 2 shows the summary of students' learning motivation and problem-solving ability data analysis.

Table 2. The summary of data analysis

\begin{tabular}{lcccccc}
\hline Variabel & \multicolumn{2}{c}{ Pre-test } & \multicolumn{2}{c}{ Post-test } & \multicolumn{2}{c}{ Z value } \\
\cline { 2 - 7 } & Mean & SD & M & SD & Calculated Z & Standard Z \\
\hline Learning Motivation & 67.21 & 5.45 & 74.98 & 5.93 & 3.43 & 1.96 \\
Problem Solving Ability & 33.43 & 4.09 & 63.54 & 2.35 & 3.43 & 1.96 \\
\hline
\end{tabular}

From Table 2 appears the pre-test score mean of students' learning motivation was $=67.21(\mathrm{SD}=5.45)$, which was at a low level, and the post-test mean score $=74.98(\mathrm{SD}=5.93)$, which was at a high level. These evidences indicate that blended learning method can increasing students learning motivation from the low level to the high level. The one-sided sign test indicated that the calculated $Z$ value $Z_{C}=3.42$. In this case, $Z_{C}>1.96$ at the significance level of $5 \%$. This means that the null hypothesis which states "there is no 
difference in students' learning motivation between before and after blended learning" was rejected. In other words, there was a significant difference in the learning motivation of prospective physics teacher students between before and after blended learning.

In detail the post-test score means of the dimensions of students learning motivation can be seen in Figure 1.

- Pre-test mean $\quad$ Post-test mean

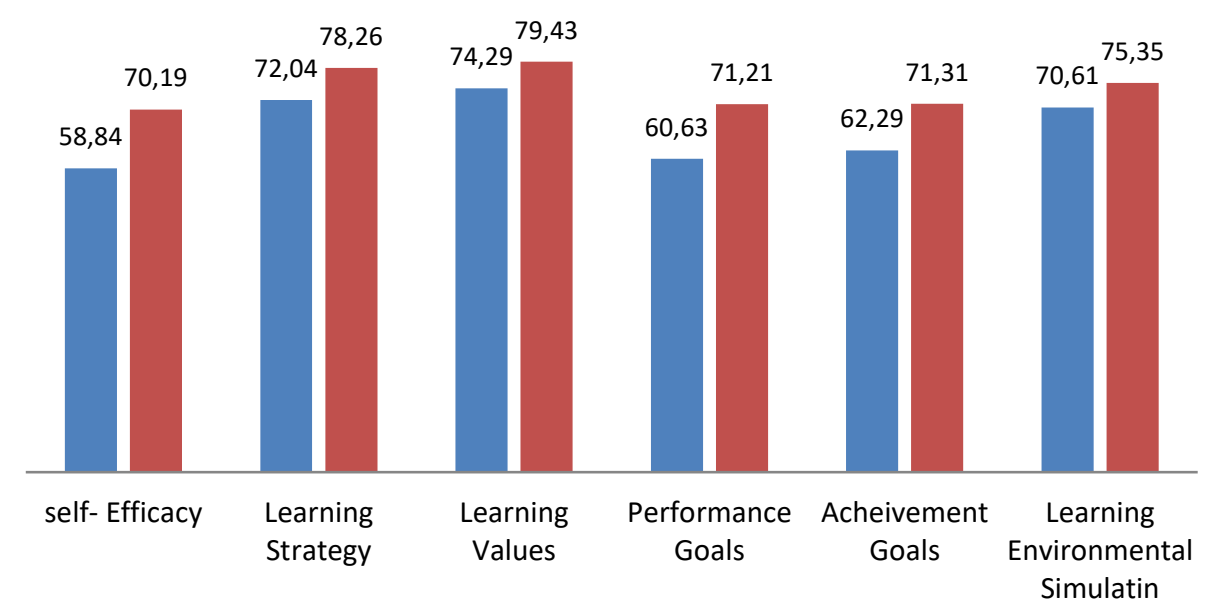

Figure 1. The Post-test Score Mean of Learning Motivation Dimensions

Figure 1 shows that there were increases of all of the learning motivation dimension mean score from before the treatment and after treatment. This consistent with the increasing of learning motivation in general. From these facts, can be concluded that blended learning can increasing prospective physics teacher students' learning motivation on mathematical physics course.

Table 01 also indicates the pre-test mean score of students' problem-solving ability was $=33.43$, with $\mathrm{SD}=4.90$, which was a very low level. Meanwhile, the post-test mean score was $=63.54$, with $S D=2.35$, which was at a medium level. These facts indicate that blended learning methods can increase students' problem-solving from the low level to the medium level. All students can pass the prescribed limit of 60.0. The one side sign test indicates that the calculated $Z$ was 3.42 , where the $Z_{\alpha}>1,96$ at a significant level of $\alpha=0.05$. This evidence indicates that the null hypothesis which states "there is no difference in students' problemsolving ability scores between before and after blended learning" was rejected. In other words, there was a significant difference in the score of the problem-solving ability of prospective physics teacher students between before and after blended learning.

Figure 2 shows problem-solving ability mean score for each dimension namely: dimension $1=$ problems visualization, dimension $2=$ physics/mathematics descriptions, dimension $3=$ plan of solution, dimension $4=$ execute the plan, and dimension $5=$ check the solution.

In Figure 2 appears that there were increasing all of the problem-solving ability dimensions from before the instruction to after the instruction. Before the instruction, all dimensions were at a low level. But, after the instruction, except dimension 1 (visualization) all the other dimensions were at a medium level. The highest mean score occurs at the problem visualization dimension, which was at a high level, and the lowest mean score occurs at the check the solution dimension. From these finding can be concluded that blended learning increasing students' problem-solving ability. 


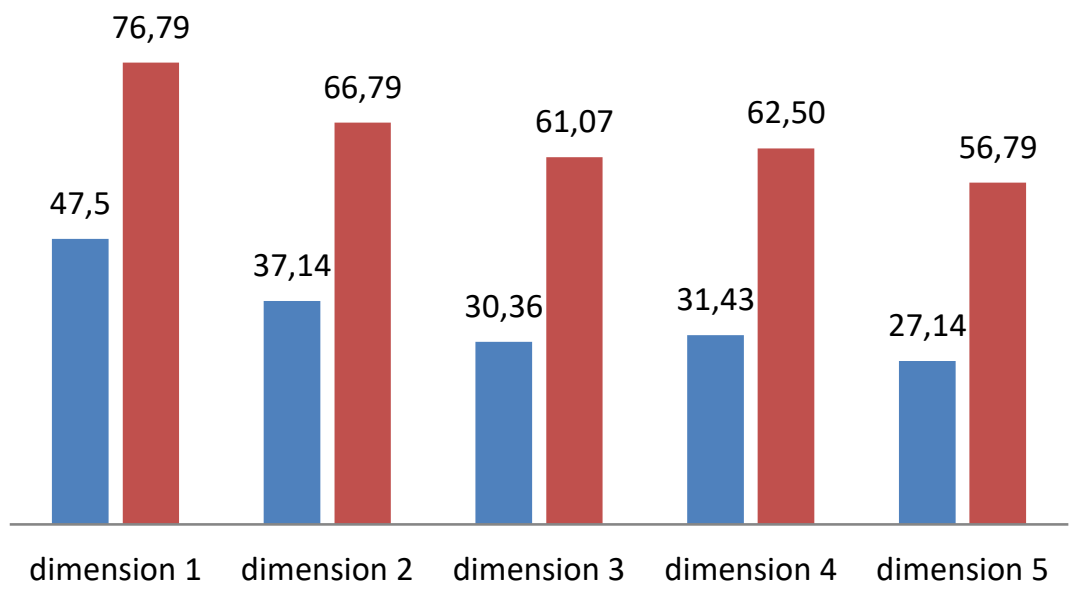

Figure 2. The Mean Score of the Dimensions of Problem-Solving Ability

The enhancement in learning motivation of prospective physics teacher students can be seen as a result of the positive response of students to blended learning. The interview results state that by online assignments students can increase their discipline, discuss online more freely without having to feel uncomfortable with classmates, study at any time and wherever, and access material online from various sources. Positive responses of students not only have an impact on increasing prospective physics teacher students' learning motivation but also increasing prospective physics teacher students' problem-solving abilities.

Through blended learning, learning carried out in offline or online mode, lecturers, and students get more time to discuss issues in class. Some topics can be studied online, while topics that feel heavy are learned face to face activities. By online learning students can access the various learning material, and interact to other students and teachers via various media quickly and easily, while through face-to-face learning, students get the guidance needed through direct social interaction (Uğur et al., 2011).

Blended learning provides broader, more complete, and freer communication coverage than traditional learning. With blended learning, students get strengthening professionalism in developing self-qualities such as self-motivation, self-responsibility, and self-discipline. Self-motivation, responsibility, and self-discipline are critical determinants of learning success. Through blended learning, students can learn according to their rhythm. They can learn wherever and whenever they want. Blended learning increases the involvement of students in learning (UNESCO, 2017), provide a wider range of educational opportunities for students (Krasnova \& Shurygin, 2019). The higher the involvement of students in learning, the learning outcomes tend to be higher. This form of blended learning helps balance learners' knowledge in groups through independent learning and assignments provided for learning and done by the instructor. There is an opportunity for students to train at a better level, to learn more complex material. So, the principle of individual approach for students can be achieved.

The findings of this research are supported by several studies such as (Alsalhi et al., 2019; Ceylan \& Elitok Kesici, 2017; Ekosiswoyo, 2016; Fazal \& Bryant, 2019; Harahap et al., 2019; Hesse, 2017; Kazu \& Demirkol, 2014; Lee et al., 2016; Oweis, 2018; Vernadakis et al., 2012; Yapici \& Akbayin, 2012). They showed that students' learning achievement who get blended learning are higher than those who study traditionally or face-to-face learning. In mathematics learning for Junior High School Students, Tseng et al., (2014) found that blended learning is significantly more effective than traditional learning. Blended learning can 
develop the character of preservice mathematics teacher students (Fisher, D. \& Kusumah, 2018).

Concerning learning motivation and attitude, (Ghazali et al., 2018; Lin et al., 2017; Oweis, 2018; Yushau, 2006) found that blended learning can develop students' motivation and attitude. Hesse, (2017) found that blended learning is effective in increasing the involvement, learning outcomes, and students' perceptions of learning. Students also develop other skills such as the ability to self-peace and self-direction. Maskar \& Wulantina, (2019) found that students feel Blended Learning makes the learning process interesting, effective, fosters motivation, fosters an attitude of independent learning, active, and creative, improve students' understanding, and learning outcomes.

The research evidence above is empirical support for the effectiveness of blended learning in a mathematical physics course in the context of developing learning motivation and problem-solving abilities. Base on this evidence, it is recommended blended learning in various subjects, to make learning more efficient, easily accessible, and improve students' ability to apply information technology. Behind the success of proving the effectiveness of blended learning in this study, there are some weaknesses that can reduce the validity of this study. First, the weaknesses of the research design. The design of this study is the onegroup pre-test post-test design. This design is not able to control other variables that can affect student learning outcomes, so whether this learning outcome is really only caused by the treatment given, it still needs to be further investigated. Second, the limitations of blended learning tools. In this study, the teaching materials provided are only textbooks, modules, lecture dictates, and sources downloaded from internet links. While there are no learning media developed according to the characteristics of participants. Third, the research time is relatively short because it follows the university's academic calendar. As a result, the mathematical physics topics used in blended learning was relatively limited. To apply blended learning, it is very important to find the characteristics of learning material, so that the learning material is suitable for online and face to face learning. This identification has not yet been carried out comprehensively and automatically not all of the mathematical physics topics have been taught with blended learning. Fourth, in this study student learning styles were not considered in the design and application of blended learning. Each student has their learning style that may be suitable for blended learning.

\section{Conclusion}

This study has combined face-to-face learning and online learning and tested its effectiveness in increasing students' learning motivation and problem-solving ability. Referring to the results of this study can be concluded: (a) The implementation of blended learning in mathematical physics course effective in developing prospective physics teacher students' learning motivation (b) Blended learning method effective in developing prospective physics teacher students' problem-solving ability. The mean score of prospective teachers' students' learning motivation was increasing from medium level to a high level. Likewise, the problem-solving ability increased from low to moderate levels. Through Blended learning, students can learn flexibly anywhere and anytime, manage their learning environment individually, and access learning material from various sources by using various media.

\section{Acknowledgment}

Thank you to Dean of Fakultas Matematika dan Ilmu Pengetahuan Alam Universitas Pendidikan Ganesha for funding this research through Research Work Agreement Letter Number: 200m / UN48.9/LT / 2019 Date: 5 February 2019.

\section{References}

Alsalhi, N. R., Eltahir, M. E., \& Al-Qatawneh, S. S. (2019). The effect of blended learning on the achievement of ninth-grade students in science and their attitudes towards its use. Heliyon, 5, 2-11. https://doi.org/10.1016/j.heliyon.2019.e02424

Arslan, A. S., \& Arslan, S. (2010). Mathematical models in physics: A study with prospective 
physics teacher. Scientific Research and Essays, 5(7), 634-640. https://doi.org/10.5897/SRE.9000642

Asquith, M. (2011). The Effects of Blended Learning Instructional Strategies and The Impact on Biology End of Course Exam Score. Thesis. Submitted to The Faculty of the Educational Specialist Program. Northwest Missouri State University. Department of Educational Leadership College of Education and Human Services.

Briggs, K. C. (2014). Blended learning vs face-to-face instruction: a quantitative evaluation of student achievement in algebra I. Northcentral University.

Çaliskan, S., Selcuk, G. S., \& Erol, M. (2010). Effects of the problem solving strategies instruction on the students' physics problem solving performances and strategy usage. Procedia Social and Behavioral Sciences, 2, 2239-2243. https://doi.org/10.1016/j.sbspro.2010.03.315

Ceylan, V. K., \& Elitok Kesici, A. (2017). Effect of blended learning to academic achievement. Journal of Human Sciences, 14(1), 308-320. https://doi.org/10.14687/jhs.v14i1.4141

Cildir, S. (2019). Improving the physics problem solving and problem posing skills of prospective physics teachers. SHS Web of Conferences, 66, 01037. https://doi.org/10.1051/shsconf/20196601037

Dziuban, C., Graham, C. R., Moskal, P. D., Norberg, A., \& Sicilia, N. (2018). Blended learning: the new normal and emerging technologies. International Journal of Educational Technology in Higher Education, 15(1), 3. https://doi.org/10.1186/s41239-017-0087-5

Ekosiswoyo, R. (2016). Kepemimpinan Kepala Sekolah yang Efektif Kunci Pencapaian Kualitas Pendidikan. Jurnal IImu Pendidikan, 14(2), 76-82. https://doi.org/10.17977/jip.v14i2.24

Fazal, M., \& Bryant, M. (2019). Blended Learning in Middle School Math: The Question of Effectiveness. Journal of Online Learning Research, 5(1), 49-64. https://www.learntechlib.org/p/183899/

Fisher, D., \& Kusumah, Y. . (2018). Developing student character of preservice mathematics teachers through blended learning. IOP Conf. Series: Journal of Physics: Conf., 1132, 2018. https://doi.org/10.1088/1742-6596/1132/1/012040/meta

Ghazali, R., Soon, C. C., Has, Z., Hassan, S. N. S., \& Hanafi, D. (2018). The Effectiveness of Blended Learning Approach with Student's Perceptions in Control Systems Engineering Course. International Journal of Human and Technology Interaction, 2(2), 103-108.

Gopalan, V., J.A., A. B., Zulkifli, A. N., Alwi, A., \& Che Mat, R. (2017). Review of the Motivation Theories in Learning. AIP Conf. Proc, 1891, 020043-1-020043-020047. https://doi.org/10.1063/1.5005376

Graham, C. R. (2006). Blended learning systems: definition, current trends, and future directions. The Handbook of Blended Learning: Global Perspectives, Local Designs, 3(21). https://doi.org/10.2307/4022859

Harahap, F., Nasution, N. E. A., \& Manurung, B. (2019). The Effect of Blended Learning on Student's Learning Achievement and Science Process Skills in Plant Tissue Culture Course. International Journal of Instruction, 2(1). https://eric.ed.gov/?id=EJ1201370

Heller, P., Keith, R., \& Anderson, S. (1992). Teaching Problem Solving Through Cooperative Grouping. Part 1: Group Versus Individual Problem Solving. American Journal of Physics, 60(7), 627-636. https://doi.org/10.1119/1.17117

Hesse, L. (2017). The effects of blended learning on K-12th-grade students. Graduate Research Papers, 116. https://scholarworks.uni.edu/grp/116 
Jung, I. S. (2001). Building a theoretical framework of Web-based instruction in the context of distance education. British Journal of Educational Technology, 32(5), 525-534. https://doi.org/10.1111/1467-8535.00222

Kaur, M. (2013). Blended learning - its challenges and future. Procedia - Social and Behavioral Sciences, 93, 612 - 617. https://doi.org/10.1016/j.sbspro.2013.09.248

Kazu, I. Y., \& Demirkol, M. (2014). Effect of blended learning environment model on high school students' academic achievement. The Turkish Online Journal of Educational Technology, 13(1), 78-87. https://eric.ed.gov/?id=EJ1018177

Krasnova, L., \& Shurygin, V. (2019). Blended Learning of Physics in the Context of the Professional Development of Teachers. International Journal of Emerging Technologies in Learning, 14(23). https://doi.org/10.1504/IJTEL.2020.103814

Lee, Y. C., Chi Lau, K., \& Yip, V. W. Y. (2016). Blended learning for building studentteachers' capacity to learn and teach science-related interdisciplinary subjects. The case of Hong Kong. Asian Association of Open Universities Journal, 11(2), 166-181. https://doi.org/10.1108/AAOUJ-09-2016-0029

Lin, Y. W., Tseng, C. ., \& Chiang, P. . (2017). The Effect of Blended Learning in Mathematics Course. EURASIA J. Math Sci-Tech, 13(3), 741-770.

Maskar, S., \& Wulantina, E. (2019). PersepsiPesertaDidikterhadapMetode Blended Learning dengan Google Classroom. Jurnal Inovasi Matematika (Inomatika), 1(2), 110-121. https://doi.org/10.35438/inomatika.v1i2.156

Mazumder, O. (2014). Student Motivation and Learning Strategies of Students from USA, China and Bangladesh. International Journal of Evaluation and Research in Education (IJERE), 3(4), 205 210. https://eric.ed.gov/?id=EJ1091729

Oh, E., \& Lim, D. (2005). Cross Relationships between Cognitive Styles and Learner Variables in the Online Learning Environment. Journal of Interactive Online Learning, 4(1), 53-66.

Oweis, T. I. (2018). Effects of Using a Blended Learning Method on Students' Achievement and Motivation to Learn English in Jordan: A Pilot Case Study. Education Research International. https://doi.org/10.1155/2018/7425924

Oxford Dictionary. (2013). Oxford Advanced Learners' Dictionary. Oxford University Press. http://oald8.oxfordlearnersdictionaries.com/dictionary/motivation\#motivate_ 43

Santrock, J. w. (2007). Psikilogi Pendidikan Terjeman Tri Wibono. KENCANA.

Shishigu, A., Hailu, A., \& Zerihun Anibo, Z. (2018). Problem-Based Learning and Conceptual Understanding of College Female Students in Physics. EURASIA Journal of Mathematics, Science and Technology Education, 14(11), 145-154. https://doi.org/10.12973/ejmste/78035

Shivam, R., \& Singh, S. (2015). Implementation of Blended Learning in the Classroom: A review paper. International Journal of Scientific and Research Publications, 5(11), 369-372. https://doi.org/10.1.1.736.2766

Stacey, E., \& Gerbic, P. (2009). Introduction to blended learning practices. In E. Stacey \& P. Gerbic (Eds.), Effective blended learning practices. Evidenced-Based Perspectives in ICT-Facilitated Education, 1-20. https://www.igi-global.com/chapter/effectiveblended-learning-practices/9185

Tseng, W.-S., Kano, T., \& Hsu, C.-H. (2014). Effect of Integrating Blended Teaching into Mathematics Learning for Junior High School Students. Journal of Computers and Applied Science Education, 1(2), 39-57. http://bit.kuas.edu.tw/ jcase/2014/vol1/JCASE-2014-02-004.pdf 
Uğur, B., Akkoyunlu, B., \& Serap Kurbanoğlu, S. (2011). The students' opinions on blended learning and its implementation in terms of their learning styles. Educ Inf Technol, 15, 5-23. https://doi.org/10.1007/s10639-009-9109-9

UNESCO. (2017). Blended Learning for Quality Higher Education: Selected Case Studies on Implementation from Asia Pacific.

Vernadakis, N., Giannousi, M., Derri, V., \& Michalopoulos, M. (2012). The impact of blended and traditional instruction in students'performance,. Procedia Technology 1, 439 443. https://doi.org/10.1016/j.protcy.2012.02.098

Volchenkova, K. (2016). Blended learning: definition, models, implication for higher. education. Educ. Sci, 8(2), 24-30. https://doi.org/10.14529/ped160204

Waynick, K. (2015). Examining Implementations of Blended Learning in a K-12 Mathematics Classroom. Honors Projects, 195. https://scholarworks.bgsu.edu/honorsprojects/195

Wichadee, S. (2013). Facilitating Students' Learning with Hybrid Instruction: A Comparison among Four Learning Styles. Electronic Journal of Research in Educational Psychology, 11(1), 099-116. https://www.redalyc.org/pdf/2931/293125761005.pdf

Williams, N.A., \& Christie, G. (2008). Improving student achievement and satisfaction by adopting a blended learning approach to inorganic chemistry. Chem. Educ. Res. Pract, 9, 43-50. https://doi.org/10.1039/B801290N

Wong, L., Tatnall, A., \& Burgess, S. (2014). A framework for investigating blended learning effectiveness. Education + Training, 56(2), 233-251. https://doi.org/10.1108/ET-042013-0049.

Yapici, I. U., \& Akbayin, H. (2012). The effect of blended learning model on high school students' biology achievement and on their attitudes towards the internet. The Turkish Online Journal of Educational Technology, 11(2), 228-237. https://eric.ed.gov/?id=EJ989031

Yen, J. C., \& Lee, C. Y. (2011). Exploring problem-solving patterns and their impact on learning achievement in a blended learning environment. Computers \& Education, 56(2), 138-145. https://doi.org/10.1016/j.compedu.2010.08.012

Yeop, M. A., Kung Teck Wong, K. T., \& Noh, M. N. (2016). Blended learning in selected journals: a content analysis using the Complex Adaptive Blended Learning Systems. International Journal of Instructional Technology and Distance Learning, 13(10), 4758.

Yushau, B. (2006). The Effects of Blended E-Learning on Mathematics and Computer Attitudes in Pre-Calculus Algebra. The Mathematics Enthusiast, 3(2), 176-183. https://scholarworks.umt.edu/tme/vol3/iss2/5/ 